Article

\title{
Surface and Physical Features of Thermo-Mechanically Modified Iroko and Tauari Wood for Flooring Application
}

\author{
Agnieszka Laskowska ${ }^{1}$ (D), Monika Marchwicka ${ }^{1}$, Agata Trzaska ${ }^{2}$ and Piotr Boruszewski ${ }^{1, *(D)}$ \\ 1 Institute of Wood Sciences and Furniture, Warsaw University of Life Science-SGGW, \\ 159 Nowoursynowska St., 02-776 Warsaw, Poland; agnieszka_laskowska@sggw.edu.pl (A.L.); \\ monika_marchwicka@sggw.edu.pl (M.M.) \\ 2 Faculty of Wood Technology, Warsaw University of Life Science-SGGW, 159 Nowoursynowska St., \\ 02-776 Warsaw, Poland; agataa.trzaska@gmail.com \\ * Correspondence: piotr_boruszewski@sggw.edu.pl; Tel.: +48-22-59-38-528
}

Citation: Laskowska, A.;

Marchwicka, M.; Trzaska, A.; Boruszewski, P. Surface and Physical Features of Thermo-Mechanically Modified Iroko and Tauari Wood for Flooring Application. Coatings 2021 11, 1528. https://doi.org/10.3390/ coatings11121528

Received: 18 November 2021 Accepted: 7 December 2021 Published: 12 December 2021

Publisher's Note: MDPI stays neutral with regard to jurisdictional claims in published maps and institutional affiliations.

Copyright: (c) 2021 by the authors. Licensee MDPI, Basel, Switzerland. This article is an open access article distributed under the terms and conditions of the Creative Commons Attribution (CC BY) license (https:// creativecommons.org/licenses/by/ $4.0 /)$.

\begin{abstract}
The aim of the study was to determine the selected surface and physical properties of iroko (Milicia excelsa (Welw.) C.C. Berg) and tauari (Couratari spp.) wood after thermo-mechanical treatment (TMT) in relation to extractive content. During TMT, no chemicals are introduced into the wood, which distinguishes this method from a number of wood modification methods. The iroko and tauari wood were subjected to volumetric densification in a hydraulic press. The wood was densified in a radial direction at a temperature of 100 and $150{ }^{\circ} \mathrm{C}$. The wood color parameters were measured using the mathematical CIE $L^{*} a^{*} b^{*}$ and $L^{*} C^{*} h$ color space models. The roughness parameters of $\mathrm{Ra}$ and $\mathrm{Rz}$ parallel and perpendicular to the grain were investigated. The contact angle (CA) of the wood with distilled water was determined based on the sessile drop method. The equilibrium moisture content (EMC) and dimensional changes of the wood were determined for a climate with a temperature of $20^{\circ} \mathrm{C}$ and a relative humidity ( $\left.\mathrm{RH}\right)$ of $9 \%, 34 \%, 55 \%, 75 \%$ and $98 \%$. The tauari wood was less prone to color changes under the influence of TMT than the iroko wood. After densification, the iroko and tauari wood displayed a different character of roughness changes. The iroko wood featured the lowest level of roughness after TMT at $100{ }^{\circ} \mathrm{C}$, and the tauari wood after TMT at $150{ }^{\circ} \mathrm{C}$. The densified iroko and tauari wood were characterized by weaker dynamics in the changes in their respective contact angles than the non-densified wood. The higher the temperature of the TMT, the lower the EMC of the wood. Higher EMC values were observed for the tauari wood than for the iroko wood. This was due to the lower content of chloroform-ethanol extractives. Similar dependencies were obtained in the case of hot water extractives. The thermo-mechanically treated wood displayed a greater tendency towards dimensional changes in a climate with high relative air humidity, i.e., above $70 \%$, compared to the non-modified wood.
\end{abstract}

Keywords: contact angle; densification; dimensional changes; equilibrium moisture content; extractives; relative humidity; sorption

\section{Introduction}

Every species of wood is characterized by specific physical and mechanical properties [1-3]. Knowing these properties results in optimal material selection for conditions of use, such as temperature, relative air humidity and class of use. Often, various modification methods are used to improve the properties of wood. One of the widely most investigated methods is thermo-mechanical treatment-TMT, often described as densification [4-7]. TMT affects a number of wood properties and is mainly focused on the production of high-density assortments translating into high wood hardness [8-10]. As an effect of TMT, the chemical properties change, resulting in, for instance, changes in the physical properties of wood [7,11,12], which are an important factor in the context of the use of wood, e.g., for flooring. 
The floor is one of the most hard-working structural elements of a building and due to its functions, it must meet a number of requirements [13-15]. Flooring materials should demonstrate high functional properties, in particular: color, low surface roughness, low wettability and high dimensional stability. High bending strength and hardness are equally important. From the environmental point of view, it is important that flooring materials be manufactured using an environment-friendly technology and be capable of being recycled. TMT of wood offers such possibilities. Unlike in the case of chemical modification, no chemicals are introduced in this wood during thermo-mechanical modification [16,17]. The eco-friendly character of this wood is also based on the fact that heat-treated wood at the end of its life cycle can be recycled without a negative impact on the environment (unlike chemically treated wood impregnated with biocidal active ingredients) [18]. Another very important aspect is that this process increases the service life of wood materials [19].

One of the quality criteria for wooden products is their geometric and dimensional accuracy. Their surface quality, mainly roughness, is equally important. The standard method used to assess wood surfaced is mainly based on the analysis of deviations, i.e., the real surface from the geometric surface. It enables the collection of information on the properties of surfaces in individual woodworking processes based on selected roughness parameters [20,21]. Surface characteristics are important in the improvement of products. Surface roughness is assessed mainly to monitor the production process. However, the main reason why the surface quality of wood is important is its aesthetics. The roughness and dimensional accuracy of wooden products must meet industry standards and customer expectations. Wettability is correlated with the roughness of wood [7,22]. The analysis of the surface properties of wooden materials is particularly important in the context of their refining (painting and varnishing) and gluing [23-26]. Often, such an analysis makes it possible to predict the behavior of wood under certain conditions. The wettability of the surface may indirectly determine the resistance of wood to moisture or chemicals.

The determination of the dimensional stability of densified wood in variable conditions is an important element of material testing [6,27-32]. Research in this area is justified due to the lack of sufficient data in published research and, above all, due to the variability in the indoor climate and its significant influence on wood properties. Within a few days, the relative air humidity in a room can drop from $65 \%$ to $30 \%-40 \%$ as a result of starting the heating system (the winter heating period). Moreover, it should be noticed that the high relative humidity of cool air is not equivalent to a high content of moisture in the air. When heated, this air becomes very dry and needs to be humidified. The variability of the outdoor climate affecting the variability of indoor climate and important climatewood interdependence prompts to undertake research on the hygroscopic properties of thermo-mechanically modified wood [33].

The ability to exchange water vapour between wood and ambient air is influenced by many factors. Wood is mainly composed of carbohydrates (ca. 70\%), i.e., cellulose and hemicelluloses, compounds whose structure features a relatively large quantity of polar hydroxyl groups - $\mathrm{OH}[34,35]$. Therefore, the higher the cellulose and hemicellulose content, the greater affinity of wood to water. According to previous research, the higher the extractives content, the lower the equilibrium moisture content of the wood [36]. In particular, compounds that are soluble in ethanol-toluene and chloroform-ethanol mixtures are considered to be hydrophobic [37]. It was stated that the surface hydrophobicity of densified wood increases as a result of migration of extractives and thermal degradation of hygroscopic wood compounds, mainly hemicelluloses $[7,38,39]$. Moreover, the higher the density of wood the greater its internal surface area and ability to exchange water vapour with the surrounding air [40].

The aim of the study was to determine the influence of thermo-mechanical treatment on selected properties of wood, which is important for its application in flooring materials, i.e., color, roughness, wettability. An investigation of the equilibrium moisture content and dimensional changes of densified wood in a climate of different relative air humidity 
was an important aspect of this study. The influence of wood extractive content on the investigated wood properties was also analyzed.

\section{Materials and Methods}

\subsection{Material}

Deciduous diffuse-porous wood, iroko (Milicia excelsa (Welw.) C.C. Berg) and tauari (Couratari spp.), was used in this study. The dimensions of the samples were: $130 \mathrm{~mm}$ (longitudinal) $\times 80 \mathrm{~mm}$ (tangential) $\times 8.50 \mathrm{~mm}$ (radial). After the samples were conditioned in a normal climate (temperature $20 \pm 2{ }^{\circ} \mathrm{C}$, relative humidity $65 \% \pm 5 \%$ ), the moisture content (MC) of the wood was determined according to ISO 13061-1:2014 [41]. The MC of the wood subjected to thermo-mechanical densification was $7.92 \%( \pm 0.68 \%)$. The wood density was determined using the stereometric method in accordance with ISO 130612:2014 requirements [42]. The surface of the wood samples was finished by planing. For non-modified wood and each variant of TMT, 20 samples were used.

\subsection{Thermo-Mechanical Modification}

The Iroko and tauari wood were subjected to thermo-mechanical treatment (TMT). The process consisted of three stages: I-heating the wood in a hydraulic press, II-wood densification, III-cooling the wood in an unheated hydraulic press without exerting pressure. Both the heating and the wood densification stages lasted $120 \mathrm{~s}$, whereas the cooling stage lasted $240 \mathrm{~s}$. The treatment was conducted at 100 and $150{ }^{\circ} \mathrm{C}$, and the unit pressure was set to $45 \mathrm{~N} \cdot \mathrm{mm}^{-2}$. The cooling of the wood was carried out in a normal climate (temperature $20 \pm 2{ }^{\circ} \mathrm{C}$, relative humidity $65 \% \pm 5 \%$ ).

The compression ratio (CR) was calculated according to Equation (1), where $t_{o}$ is the original thickness $(\mathrm{mm})$, and $t_{d}$ is the thickness of wood after densification $(\mathrm{mm})$ :

$$
\mathrm{CR}=\frac{\mathrm{t}_{\mathrm{o}}-\mathrm{t}_{\mathrm{d}}}{\mathrm{t}_{\mathrm{o}}} \times 100(\%)
$$

\subsection{Extractives and $1 \% \mathrm{NaOH}$ Soluble Substances Content}

The iroko and tauri wood were milled in a laboratory mill, Retsch SM100 (Retsch $\mathrm{GmbH}$, Haan, Germany). The fraction that passed through the sieves with $1.0 \mathrm{~mm}$ mesh and remained on the sieves with $0.5 \mathrm{~mm}$ mesh was used for the investigation. Chloroformethanol extraction of the wood was performed according to TAPPI T 264 om-88, with modifications [43]. A mixture of benzene-ethanol was replaced by a mixture of chloroformethanol $(93: 7 w / w)$ [37]. About $3 \mathrm{~g}$ of wood were extracted for $10 \mathrm{~h}$ in a Soxhlet apparatus (Glassco Laboratory Equipments, Manglai, India), keeping the liquid boiling so the siphoning from the extractor was about $10 \mathrm{~min}$. Hot water extraction of the wood was performed according to TAPPI T $207 \mathrm{~cm}-99$ [44]. For the determination of the hot water solubility, $3 \mathrm{~g}$ of wood were extracted under a reflux in a boiling water bath for $3 \mathrm{~h}$. Wood was also extracted with 1\% sodium hydroxide solution using TAPPI T 212 om-12 with modification [45]. Extraction was performed on wood samples of $1 \mathrm{~g}$ under the reflux in a water bath at $100{ }^{\circ} \mathrm{C}$ for $1 \mathrm{~h}$. The content of the soluble substances in a given solvent was expressed as a percentage of dry mass of the wood.

Each measurement was repeated four times. The mass measurements were carried out to a precision of $0.001 \mathrm{~g}$. Chloroform, analytical grade, was purchased from Chempur Company (Piekary Śląskie, Poland); sodium hydroxide, analytical grade, from Avantor Performance Materials Poland S.A. (Gliwice, Poland); and ethanol, technical grade, from Linegal Chemicals Company (Warsaw, Poland).

\subsection{Color Parameter Measurements}

The measurement of wood color was based on the mathematical models of color space-CIE $L^{*} a^{*} b^{*}$ and $L^{*} C^{*} h$. The lightness $\left(L^{*}\right)$, chromatic coordinate on the red-green axis $\left(a^{*}\right)$ and chromatic coordinate on the yellow-blue axis $\left(b^{*}\right)$, the parameters $C^{*}$ (saturation, color intensity) and $\mathrm{h}$ (hue angle) were determined. The color difference $\Delta \mathrm{E}$ was 
carried out in accordance with ISO 7724-3:1984 [46]. The color parameters were determined by using colorimeter NH300 company 3nh ${ }^{\circledR}$ (Shenzhen, China). The sensor head was $8 \mathrm{~mm}$ in diameter. The measurements were performed using a D65 illuminant. In total, 20 measurements were performed for the non-modified wood and each variant of the thermo-mechanically modified wood.

\subsection{Roughness Parameters}

The roughness was examined in accordance with the ISO 4287:1997 requirements [47]. The $\mathrm{Ra}$ (arithmetical mean deviation of the assessed profile) and $\mathrm{Rz}$ (maximum height of the assessed profile) parameters, defined in ISO 4287:1997 [47], were measured. The surface roughness was determined using the Surftest SJ-210- Series 178-Portable Surface Roughness Tester manufactured by Mitutoyo Corporation (Kawasaki, Japan). The parameters were measured parallel and perpendicular to the grain, 20 times in each direction for the nonmodified wood and each variant of the modified wood.

\subsection{Wettability Determination}

The contact angles of the wood (before and after TMT) with the distilled water were determined in a goniometer Phoenix 300 of Surface Electro Optics company (Suwon City, Korea), based on the sessile drop method. The volume of the drop applied to the surface of wood was $3 \mu \mathrm{L}$. The values of the contact angle were determined after 3, 30, and $60 \mathrm{~s}$ after the application of a liquid drop on the surface of the wood. This made it possible to determine the dynamics of changes in the wettability angle in time. The studies were performed after conditioning the samples in a normal climate (temperature $20 \pm 2{ }^{\circ} \mathrm{C}$, relative humidity $65 \% \pm 5 \%$ ). In total, 12 measurements were performed for the nonmodified wood and for each variant of the thermo-mechanically modified wood.

\subsection{Equilibrium Moisture Content and Dimensional Changes of Wood}

Wood samples with dimensions of $80 \mathrm{~mm}$ (tangential) $\times 12 \mathrm{~mm}$ (longitudinal) were used for the equilibrium moisture content (EMC) determination. The thickness of the control samples was $8.65( \pm 0.38) \mathrm{mm}$ and in the case of modified samples, it corresponded to the thickness of the samples after TMT. The samples were dried to a constant weight $(0 \%$ MC). Next, the samples were placed into containers in which the relative humidity (RH) was $9 \%$ to $98 \%$ at $20{ }^{\circ} \mathrm{C}\left( \pm 2{ }^{\circ} \mathrm{C}\right)$. Wood conditioning at various $\mathrm{RH}$ conditions was obtained using saturated solutions of chemicals (Table 1). All the chemicals for this test were p.a. (pure-for-analysis) grade. The chemicals were obtained from Chempur (Piekary Ślaskie, Poland). The determination of sorption (adsorption) was completed when the mass of the wood samples remained unchanged over three weighings at $48 \mathrm{~h}$ intervals. Anemometer AZ 9871 (AZ Instrument Corp., Taichung City, Taiwan) was used to measure the RH.

Table 1. Saturated solution of chemicals used to obtain appropriate relative humidity (RH).

\begin{tabular}{ccc}
\hline \multicolumn{2}{c}{ Saturated Solution } & RH (\%) \\
\hline $\mathrm{KOH}$ & Potassium hydroxide & 9 \\
$\mathrm{MgCl}_{2} \cdot 6 \mathrm{H}_{2} \mathrm{O}$ & Magnesium chloride & 34 \\
$\mathrm{NaBr}$ & hexahydrate & 55 \\
$\mathrm{NaCl}$ & Sodium bromide & 75 \\
$\mathrm{~K}_{2} \mathrm{SO}_{4}$ & Sodium chloride & 98 \\
\hline
\end{tabular}

Dimensional changes in the radial and tangential directions were determined which related to the changes in the thickness and width of the conditioned samples, respectively. The measurements were carried out with an accuracy of $0.001 \mathrm{~mm}$. Linear swelling for 
the radial $S_{r}$ and tangential $S_{t}$ direction was calculated according to Equations (2) and (3), respectively:

$$
\begin{aligned}
& S_{r}=\frac{r_{c}-r_{o}}{r_{o}} \times 100(\%) \\
& S_{t}=\frac{t_{c}-t_{o}}{t_{o}} \times 100(\%)
\end{aligned}
$$

where: $r_{o}$ or $t_{o}$ are the dimensions $(\mathrm{mm})$ of the wood samples at absolutely dry (oven-dry) condition, measured in the radial and tangential directions, respectively; and $\mathrm{r}_{\mathrm{c}}$ or $\mathrm{t}_{\mathrm{c}}$ are the dimensions $(\mathrm{mm})$ of the wood samples conditioned at different $\mathrm{RH}$, measured in the radial and tangential directions, respectively.

The volumetric swelling (VS) of the wood at different RH was determined according to Equation (4):

$$
\mathrm{VS}=\frac{\mathrm{V}_{\mathrm{c}}-\mathrm{V}_{\mathrm{o}}}{\mathrm{V}_{\mathrm{o}}} \times 100(\%)
$$

where $V_{o}$ is the volume $\left(\mathrm{mm}^{3}\right)$ of the wood samples at oven-dry condition, and $V_{c}$ is the volume $\left(\mathrm{mm}^{3}\right)$ of the wood samples conditioned at different $\mathrm{RH}$.

\subsection{Statistical Analysis}

The statistical analyses were performed using the STATISTICA version-12 software (TIBCO Software Inc., Palo Alto, CA, USA). The statistical analysis of the results was based on the $t$-test or the ANOVA (Fischer's F-test), with a significance level ( $p$ ) of 0.05 . Based on the sum of squares (SS), the percentual impact of the analyzed factors (i.e., species, modification temperature), the so-called factor influence, on the densified wood, was calculated.

\section{Results}

\subsection{The Compression Ratio and Density of Thermo-Mechanically Modified Wood}

Wood densification affects a number of wood properties, including density. The density and compression ratio (CR) of the densified iroko and tauari wood are summarized in Table 2. The values of the non-densified iroko and tauari wood density were comparable to data from previous research $[1,48]$. The iroko wood was characterized by lower susceptibility to densification than tauari wood. The areas of irregular fibers in the iroko wood were less susceptible to TMT than those with straight fibers in tauari wood. It was observed that a high modification temperature, at $150{ }^{\circ} \mathrm{C}$, exerted a negative impact on the iroko wood. This was due to the lower $\mathrm{CR}$ of iroko wood at $150{ }^{\circ} \mathrm{C}$ than at $100^{\circ} \mathrm{C}$ (Table 2). The tauari wood displayed a more "regular" structure and higher density than the iroko wood. Therefore, it was densified to a higher value.

Table 2. The compression ratio (CR) and density of thermo-mechanically modified iroko and tauari wood; $\pm(\mathrm{SD})$.

\begin{tabular}{cccc}
\hline Wood Species & Modification Temperature $\left({ }^{\circ} \mathbf{C}\right)$ & CR (\%) & Density $\left(\mathbf{k g} \cdot \mathbf{m}^{-3}\right)$ \\
\hline \multirow{2}{*}{ iroko } & non-modified & - & $564 \pm 29$ \\
& 100 & $34 \pm 2$ & $769 \pm 15^{*}$ \\
& 150 & $32 \pm 3$ & $732 \pm 33^{*}$ \\
\multirow{2}{*}{ tauari } & non-modified & - & $694 \pm 41$ \\
& 100 & $30 \pm 3$ & $974 \pm 26^{*}$ \\
& 150 & $35 \pm 3$ & $1098 \pm 27^{*}$ \\
\hline
\end{tabular}

* Statistically significant differences within the same species, based on the $t$-test ( $p \leq 0.05$; control group-nonmodified wood).

One of the features of wood that determines its technological properties is its density. It is also the most frequently measured parameter because it determines the physical and mechanical properties as well as the technological quality of wood. This is confirmed 
by previous research $[10-12,49]$. The density of tauari wood modified at 100 and $150{ }^{\circ} \mathrm{C}$ was $27 \%$ and $50 \%$ higher, respectively, than the density of iroko wood modified at the same temperatures. The modification temperature had a greater impact on the density of the tauari wood than on the density of the iroko wood. The density of the iroko wood densified at 100 and $150{ }^{\circ} \mathrm{C}$ was higher by $36 \%$ and $30 \%$, respectively, than that of the nonmodified iroko wood. Pelit and Emiroglu [49] stated that the density values of wood tend to decrease due to spring-back increase in wood as a result of compression temperature increase. The density of aspen wood after densification at $120^{\circ} \mathrm{C}$ (compression ratio $20 \%$ ) was higher by $30 \%$, and after densification at $180{ }^{\circ} \mathrm{C}$ by $20 \%$ higher than the density of undensified aspen wood. In iroko wood, this phenomenon can be enhanced by the irregular fiber arrangement. İmirzi et al. [50] demonstrated that the density of Scots pine rose from $430 \mathrm{~kg} \cdot \mathrm{m}^{-3}$ to $810 \mathrm{~kg} \cdot \mathrm{m}^{-3}$ after densification at $140{ }^{\circ} \mathrm{C}$ and to $800 \mathrm{~kg} \cdot \mathrm{m}^{-3}$ after densification at $160^{\circ} \mathrm{C}$. Generally, increasing the densification temperature did not affect the density. The density of the tauari wood densified at $100{ }^{\circ} \mathrm{C}$ was $40 \%$ higher than that of the non-densified tauari wood, whereas the tauari densified at $150{ }^{\circ} \mathrm{C}$ exhibited a $58 \%$ higher density than the non-densified tauari wood. The density values of the tauari wood after densification were comparable to the density of poplar (Populus alba L.) and birch wood (Betula pendula Roth.) observed by Mania et al. [12]. The density of densified wood depends on many factors $[8,51,52]$. However, by selecting the appropriate processing parameters, it is possible to obtain the assumed wood density [53].

\subsection{The Content of Soluble Substances}

In the non-modified iroko wood, there were three times more chloroform-ethanol extractives, twice more hot water extractives and $1 \% \mathrm{NaOH}$ soluble substances than in the tauari wood (Table 3). Similar relationships occurred after TMT at $100{ }^{\circ} \mathrm{C}$. After TMT at $150{ }^{\circ} \mathrm{C}$, the iroko wood displayed 4 times more chloroform-ethanol extractives, 1.5 times more hot water extractives and 2 times more $1 \% \mathrm{NaOH}$ soluble substances than the tauari wood. Due to the low content of extractives in the tauari wood, their changes (expressed as a percentage of the dry mass of the wood) were greater under the influence of TMT.

Table 3. The content of extractives and $1 \% \mathrm{NaOH}$ soluble substances in thermo-mechanically modified iroko and tauari wood; $\pm(\mathrm{SD})$.

\begin{tabular}{ccccc}
\hline \multirow{2}{*}{$\begin{array}{c}\text { Wood } \\
\text { Species }\end{array}$} & $\begin{array}{c}\text { Modification } \\
\text { Temperature }\left({ }^{\circ} \mathbf{C}\right)\end{array}$ & $\begin{array}{c}\text { Extractives (\%) } \\
\text { Chloroform- } \\
\text { Ethanol }\end{array}$ & Hot Water & $\begin{array}{c}\text { Soluble } \\
\text { Substances in 1\% } \\
\text { NaOH (\%) }\end{array}$ \\
\hline \multirow{2}{*}{ iroko } & non-modified & $7.3 \pm 0.4$ & $4.7 \pm 0.2$ & $22.7 \pm 0.2$ \\
\cline { 2 - 5 } & 100 & $6.5 \pm 0.3$ & $4.7 \pm 0.1$ & $21.2 \pm 0.6^{*}$ \\
\cline { 2 - 5 } & 150 & $6.9 \pm 0.3$ & $4.5 \pm 0.2$ & $21.2 \pm 0.5^{*}$ \\
\hline \multirow{2}{*}{ tauari } & non-modified & $2.6 \pm 0.2$ & $2.3 \pm 0.1$ & $11.8 \pm 0.3$ \\
\cline { 2 - 5 } & 100 & $1.9 \pm 0.2^{*}$ & $2.3 \pm 0.1$ & $10.7 \pm 0.4^{*}$ \\
\cline { 2 - 5 } & 150 & $1.7 \pm 0.2^{*}$ & $3.1 \pm 0.1 *$ & $10.6 \pm 0.1^{*}$ \\
\hline
\end{tabular}

* Statistically significant differences within the same species, based on the $t$-test $(p \leq 0.05$; control group, nonmodified wood).

As a result of the TMT of the iroko wood, statistically significant differences occurred only in the content of the $1 \% \mathrm{NaOH}$ soluble substances. However, in the tauari wood, TMT also caused significant changes in the content of chloroform-ethanol extractives and hot water extractives. In all the analyzed cases, the content of soluble substances decreased with the increase in the modification temperature. The exception was the hot water extractives in the tauari wood, whose number increased after TMT. Cruz et al. [13] found similar dependencies in the case of acetone extractives in Pinus radiata wood after densification. Depending on the type, extractive compounds behave differently during the thermal treatment of wood. Most of the native extractives are progressively lost or 
degraded as the process temperature increases. Some degradation products are removed by the emission, such as carbon dioxide, methanol, acetic acid and formic acid, while non-volatile degradation products often remain in the wood [54]. The extractives content is decreased by the loss of volatile extractives and degradation products and increased by new extractable compounds (products of thermal degradation of carbohydrates) [55]. Therefore, it is difficult to determine whether the total content of extractives in thermally modified wood will increase or decrease in the applied temperature range. This will depend not only on the modification conditions of the wood, but also on which of the processes described will exert a greater effect; therefore, it will depend on the species of wood, the content and the type of extractives.

\subsection{Wood Color}

On the basis of organoleptic observations, noticeable changes in the color of the iroko and tauari wood were found under the influence of thermo-mechanical modification (Figure 1). The results of the organoleptic observations confirm the numerical values. The color parameters displayed the greatest variation, depending on the wood species (Table 4).

\begin{tabular}{cccc}
\hline Wood & Non-Modified & Modified at $100^{\circ} \mathrm{C}$ & Modified at $150{ }^{\circ} \mathrm{C}$ \\
\hline iroko & & & \\
& & & \\
\hline tauari & & & \\
& & & \\
\hline
\end{tabular}

Figure 1. Iroko and tauari wood before and after thermo-mechanical modification.

Table 4. Color parameters and total color change $(\Delta \mathrm{E})$ of thermo-mechanically modified wood; $\pm(\mathrm{SD})$.

\begin{tabular}{|c|c|c|c|c|c|c|c|}
\hline \multirow{2}{*}{$\begin{array}{l}\text { Wood } \\
\text { Species }\end{array}$} & \multirow{2}{*}{$\begin{array}{c}\text { Modification } \\
\text { Temperature }\left({ }^{\circ} \mathrm{C}\right)\end{array}$} & \multicolumn{5}{|c|}{ Parameters } & \multirow{2}{*}{$\Delta \mathrm{E}$} \\
\hline & & $\mathbf{L}^{*}$ & $a^{*}$ & $\mathbf{b}^{*}$ & $C^{*}$ & $\mathbf{h}$ & \\
\hline \multirow{3}{*}{ iroko } & non-modified & $63.94 \pm 1.41$ & $7.59 \pm 0.65$ & $26.67 \pm 0.72$ & $27.74 \pm 0.74$ & $74.13 \pm 1.28$ & - \\
\hline & 100 & $59.55 \pm 1.32 *$ & $9.03 \pm 0.46^{*}$ & $25.55 \pm 0.58^{*}$ & $27.92 \pm 0.47$ & $70.53 \pm 1.21 *$ & $4.81 \pm 1.52$ \\
\hline & 150 & $56.83 \pm 3.58 *$ & $9.71 \pm 0.91 *$ & $24.67 \pm 1.33^{*}$ & $28.35 \pm 2.98$ & $69.81 \pm 2.43^{*}$ & $8.07 \pm 2.13$ \\
\hline \multirow{3}{*}{ tauari } & non-modified & $65.30 \pm 1.82$ & $4.71 \pm 0.30$ & $20.50 \pm 0.98$ & $21.04 \pm 0.96$ & $77.05 \pm 0.98$ & - \\
\hline & 100 & $63.00 \pm 2.21 *$ & $4.89 \pm 0.52$ & $21.44 \pm 0.87^{*}$ & $21.99 \pm 0.88^{*}$ & $77.16 \pm 1.31$ & $3.57 \pm 1.00$ \\
\hline & 150 & $62.67 \pm 1.79 *$ & $4.92 \pm 0.26$ & $22.38 \pm 1.15^{*}$ & $22.89 \pm 1.15^{*}$ & $77.80 \pm 0.60 *$ & $3.67 \pm 0.97$ \\
\hline
\end{tabular}

* Statistically significant differences within the same species, based on the $t$-test ( $p \leq 0.05$; control group, non-modified wood).

The color parameters of the iroko wood, i.e., $\mathrm{L}^{*}, \mathrm{a}^{*}, \mathrm{~b}^{*}$ and $\mathrm{h}$, changed significantly after densification at a temperature of $100{ }^{\circ} \mathrm{C}$. After TMT, the color of the iroko wood was darker and changed mainly towards red. This color can be associated with the extractives content [56], which was higher in the iroko wood than in the tauari wood (Table 3). After modification at $150{ }^{\circ} \mathrm{C}$, the iroko wood featured two times higher total color changes $(\Delta \mathrm{E})$ values than after modification at $100{ }^{\circ} \mathrm{C}$. In the case of the tauari wood, TMT at a temperature of $100^{\circ} \mathrm{C}$ caused significant changes in $\mathrm{L}^{*}, \mathrm{~b}^{*}, \mathrm{C}^{*}$. However, after the tauari wood's densification at a temperature of $150{ }^{\circ} \mathrm{C}$, there were additional changes in the values of the $h$ parameter. After TMT, the color of the tauari wood was darker and changed mainly towards yellow. This resulted from the photochemistry of lignin [57]. Regardless of 
the modification temperature, $\Delta \mathrm{E}$ for the tauari wood was at a similar level and amounted to approximately 3.5. According to the evaluation criteria of the overall color change, when $\Delta \mathrm{E}$ is between 3 and 6 , color change is visible with a medium-quality filter; significant color changes occur when $\Delta \mathrm{E}$ is between 6 and 12; and when the value is above 12 , it is considered a different color [58]. On this basis, it can be concluded that high color changes occurred after the densification of the iroko wood at $150{ }^{\circ} \mathrm{C}$.

The statistical data demonstrate that the wood species determined all the analyzed color parameters, and thus $\Delta \mathrm{E}$ (Figure 2). The wood species exerted the greatest impact on the $\mathrm{a}^{*}$ (impact at the level of $85 \%$ ), slightly less on $\mathrm{C}^{*}, \mathrm{~b}^{*}, \mathrm{~h}$ (impact at the level of $79 \%$, $75 \%, 70 \%$, respectively) and even less on $\mathrm{L}^{*}(25 \%$ impact). The modification temperature influenced all the analyzed color parameters of the iroko and tauari wood, with the exception of $b^{*}$. The influence of temperature (for the tested levels of 100 and $150^{\circ} \mathrm{C}$ ) was much smaller than in the case of the wood species. The modification temperature exerted the greatest impact on $L^{*}$ (impact at the level of 33\%); in the case of other parameters, the impact was below $6 \%$. The influence of interaction between species and modification temperature was significant for $\mathrm{L}^{*}, \mathrm{a}^{*}, \mathrm{~b}^{*}, \mathrm{~h}$ and, consequently, $\Delta \mathrm{E}$. However, depending on the parameter, it was relatively small and ranged from $4 \%$ to $12 \%$. From the error value, it can be concluded that there are other factors that significantly determine wood color. It is known from previous research that wood color depends on many factors, e.g., age, moisture content, extractive content, soil water [59,60] and wood drying conditions [61].

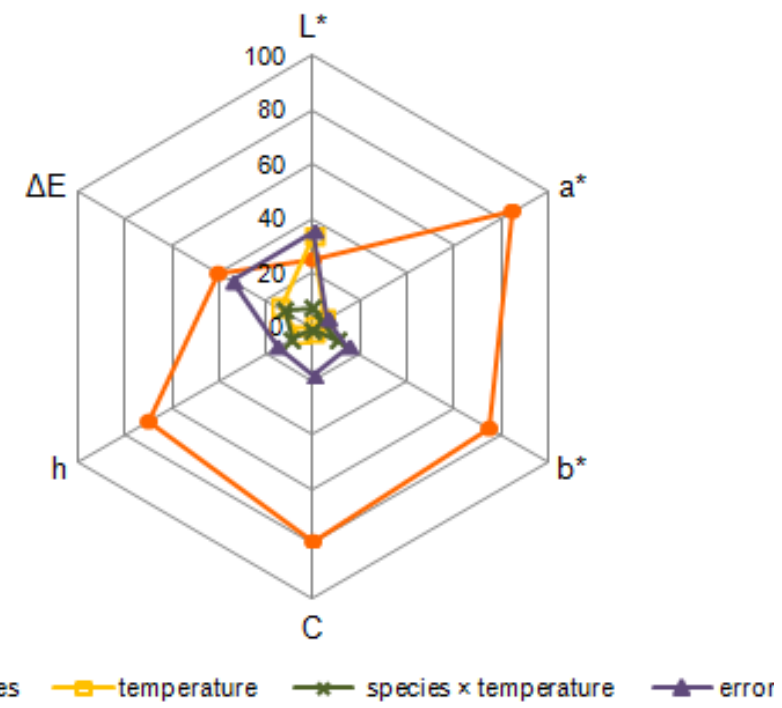

Figure 2. Factors influencing the color parameters and total color change $(\Delta \mathrm{E})$ of thermo-mechanically modified iroko and tauari wood (Fischer's F-test; $p \leq 0.05$ ).

\subsection{Wood Roughness after TMT}

As a TMT effect, the wood becomes densified, which results in a decrease in the volume of voids in the wood, an increase in density and, thus, lower roughness. The size of these changes depends on the characteristics of the raw material and the parameters of the process $[18,39]$. This is also confirmed by the data presented in Figure 3. As the modification temperature increased, the roughness of the tauari wood, measured parallel $(\|)$ and perpendicular $(\perp)$ to the fibers, expressed by the Ra (Figure $3 b$ ) and $\mathrm{Rz}$ (Figure $3 \mathrm{~d}$ ) parameters, was lower. Similar relationships were observed for thermally compressed Douglas fir (Pseudotsuga menziesii (Mirb.) Franco) veneers [18]. By contrast, iroko wood densified at $150{ }^{\circ} \mathrm{C}$ displayed similar $\mathrm{Ra}$ and $\mathrm{Rz}$ values parallel to the fibers to the $\mathrm{Ra}$ and $\mathrm{Rz}$ values after TMT in $100^{\circ} \mathrm{C}$, respectively. On the other hand, higher values of Ra and $\mathrm{Rz}$ perpendicular to the fibers were found for the iroko wood densified in $150{ }^{\circ} \mathrm{C}$ than at $100^{\circ} \mathrm{C}$. This was due to the densification of the iroko wood samples to a lower level of thickness, i.e., obtaining lower $\mathrm{CR}$ after densification at $150{ }^{\circ} \mathrm{C}$ than at $100{ }^{\circ} \mathrm{C}$ (Table 2). 
A similar direction of changes in roughness was demonstrated by İmirzi et al. [50] after the densification of Scots pine (Pinus sylvestris L.). The authors indicated that the lowest roughness was obtained in the densified specimens at $140{ }^{\circ} \mathrm{C}$; raising the temperature to $160{ }^{\circ} \mathrm{C}$ increased the roughness.

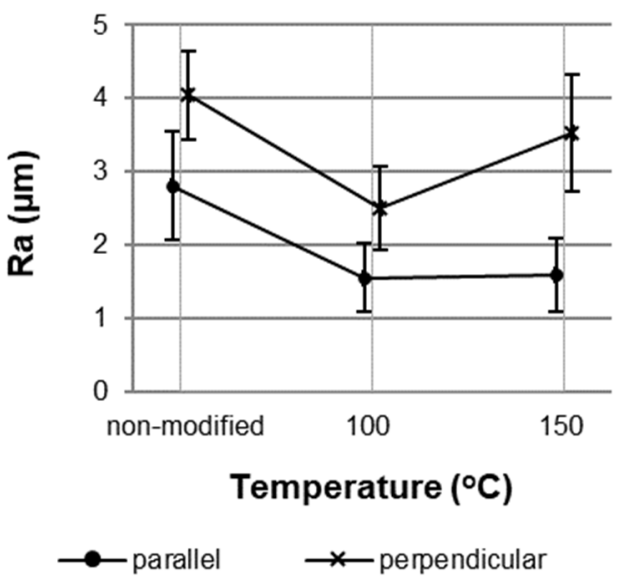

(a)

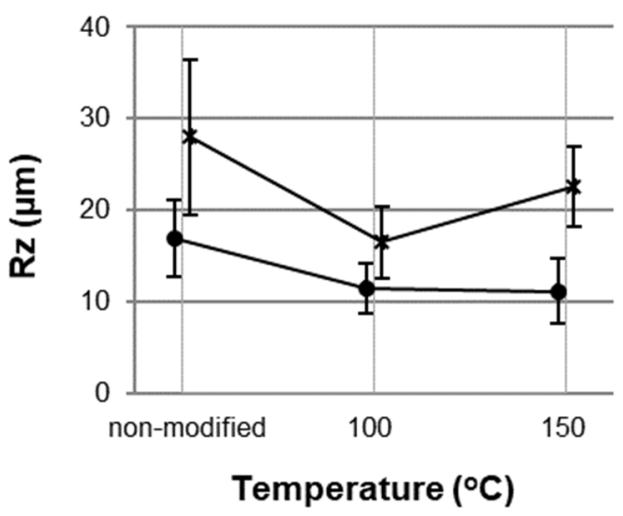

$\longrightarrow$ - parallel

(c)

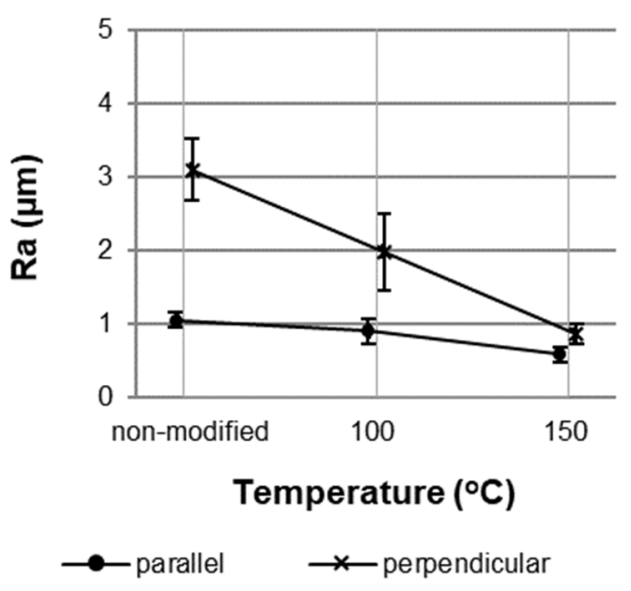

(b)

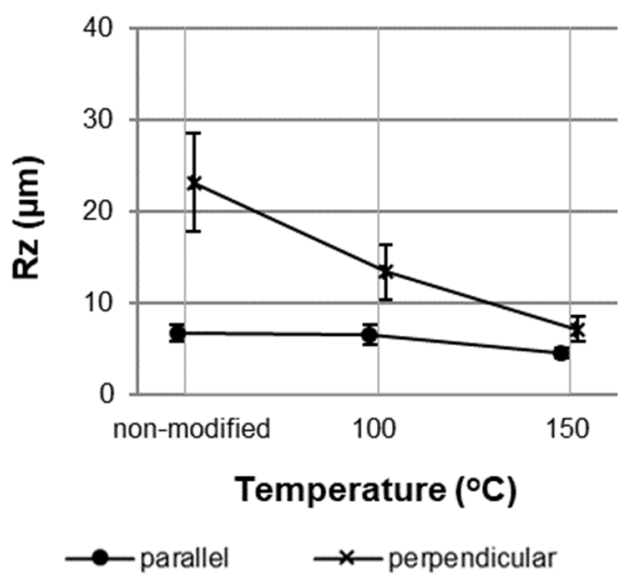

(d)

Figure 3. Roughness parameters of (a) Ra and (c) Rz of iroko wood and (b) Ra (d) Rz of tauari wood.

In general, it can be concluded that the iroko wood featured the lowest level of roughness after densification at $100{ }^{\circ} \mathrm{C}$, and the tauari wood after densification at $150{ }^{\circ} \mathrm{C}$. For these conditions, the $\mathrm{Ra}_{\|}$of the densified iroko wood was about twice as low as the $\mathrm{Ra}_{\|}$ of thee non-densified iroko wood. The $\mathrm{Ra}_{\perp}$ of the densified iroko wood was about 1.5 times lower than the $\mathrm{Ra}_{\perp}$ of the non-densified iroko wood, whereas the $\mathrm{Ra}_{\|}$of the densified tauari wood was about twice as low as the $\mathrm{Ra}_{\|}$of the non-densified tauari wood. The $\mathrm{Ra}_{\perp}$ of the densified tauari wood was about four times lower than the $\mathrm{Ra}_{\perp}$ of the non-densified tauari wood. By analyzing the second parameter, it was demonstrated that the $\mathrm{Rz}_{\|}$of the densified iroko wood was about 1.5 times lower than the $\mathrm{Rz}_{\|}$of the non-densified iroko wood. The $\mathrm{Rz}_{\perp}$ of the densified iroko wood was about twice as low as the $\mathrm{Rz}_{\perp}$ of the non-densified iroko wood, whereas the $\mathrm{Rz}_{\|}$of the densified tauari wood was about 1.5 times lower than the $\mathrm{Rz}_{\|}$of the non-densified tauari wood. The $\mathrm{Rz}_{\perp}$ of the densified tauari wood was about three times lower than the $\mathrm{Rz}_{\perp}$ of the non-densified tauari wood.

Analyzing the relationships between the species and taking into account the fact that the iroko wood featured the lowest level of roughness after densification at $100{ }^{\circ} \mathrm{C}$ and the tauari wood after densification at $150{ }^{\circ} \mathrm{C}$, it was demonstrated that the $\mathrm{Ra}_{\|}$of the densified tauari wood was three times lower than the $\mathrm{Ra}_{\|}$of the densified iroko wood. Similar relationships were noted for the $\mathrm{Ra}_{\perp}$ between the species. On the other hand, the $\mathrm{Rz} \|$ of 
the densified tauari wood was 2.5 times lower than the $\mathrm{Rz}_{\|}$of the densified iroko wood. Similar relationships were noted for the $\mathrm{Rz}_{\perp}$ the between species.

Wood roughness is the result of the wood's anatomical structure and the conditions of the densification process $[7,62]$. When the wood surface is exposed to high temperatures, the degradation of hemicelluloses and cellulose on the surface increases the surface roughness, while the cells on the wood surface are compressed due to the densification process, and the roughness value decreases. Iroko wood features vessels with diameters of $65-320 \mu \mathrm{m}$ (average $190 \mu \mathrm{m}$ ); their share is $8 \%-17 \%$. Fibers, whose share is in the range of $44 \%-70 \%$, feature a lumina diameter of 2.4-22.0 $\mu \mathrm{m}$ (average $12.0 \mu \mathrm{m}$ ) [1]. Vessels in tauari wood feature a diameter of $94-312 \mu \mathrm{m}$, while that of fibers is 11-16 $\mu \mathrm{m}$ [63]. The depth of the cracks caused by machining may even be of millimetric dimensions. The pores and cracks were diminished by TMT; this effect was clearly seen by the applied surface measurements.

It is well known that the surface properties of wood materials influence the gluing, impregnation and finishing processes [23-26] and that they can be assessed using many techniques. Knowledge of the surface parameters of materials determines the selection of the method of their finishing as well as the parameters related to the gluing process. It also makes it possible to determine the resistance of wood to moisture or chemicals. The selection of a pre-treatment process for the wood surface prior to finishing to achieve the optimal relationship between the finish and the wood can be difficult; however, it is of great importance for the properties of the finished products. It is also influenced by the surface quality of the material, defined in terms of roughness, which is strongly correlated with the wettability $[7,22]$.

\subsection{Contact Angle}

TMT caused changes in the wettability of the iroko (Figure 4a) and tauari (Figure 4b) wood, expressed through a higher contact angle.

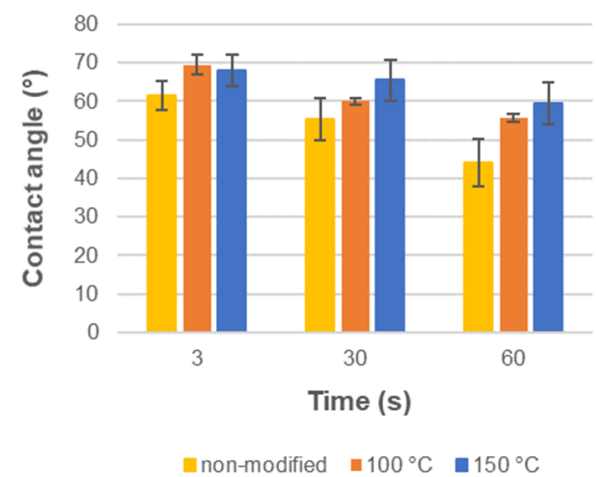

(a)

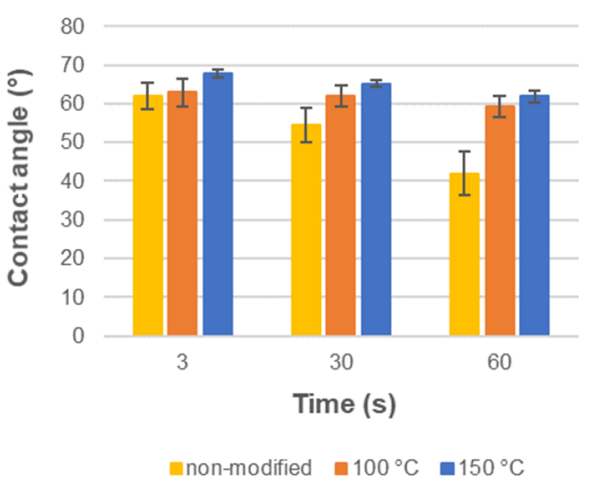

(b)

Figure 4. Contact angle of (a) iroko and (b) tauari wood before and after thermo-mechanical treatment.

No significant differences were found between the contact angle values for the iroko and tauari wood. This applied to both non-densified and densified wood. The higher the modification temperature, the lower the wettability of the wood. This was the effect of changes in the roughness of the wood surface $[64,65]$ and chemical changes occurring in the wood under the influence of TMT [7]. Bekhta et al. [66] found that veneer surfaces became more hydrophobic for all of the wood species they investigated (alder, beech, birch and pine) at temperatures between 150 and $200{ }^{\circ} \mathrm{C}$. The changes in the contact angle were lower for the densified wood than for the non-densified wood. It was shown that from $60 \mathrm{~s}$ after the application of a drop of water on the surface of non-modified wood, the contact angle was approximately $30 \%$ lower than after $3 \mathrm{~s}$. However, from $60 \mathrm{~s}$ after applying a 
drop of water on the surface of TMT wood, the contact angle was approximately $10 \%$ lower than after $3 \mathrm{~s}$.

The conducted research demonstrates that the influence of temperature modification on the contact angle was statistically significant (Table 5). From the error value, it can be concluded that there are other factors that significantly affect the contact angle i.e., the type of wetting liquid, the wood porosity [7], and the "nature" of the chemical components of the wood at different treatment temperatures [67].

Table 5. Statistical evaluation of the factors influencing the contact angle of iroko and tauari wood (based on ANOVA, Fischer's F-test, $p \leq 0.05$ ).

\begin{tabular}{ccccc}
\hline Contact Angle & Factor & Fisher's F-test & Significance Level & $\begin{array}{c}\text { Factor } \\
\text { Influence (\%) }\end{array}$ \\
\cline { 1 - 4 } & - & $\mathbf{F}$ & $\boldsymbol{p}$ & 7 \\
after 3 s & Species (1) & 3.23 & $0.082482 \mathrm{NS}$ & 29 \\
& Temperature (2) & 7.20 & $0.002800^{*}$ & 3 \\
& $(1) \times(2)$ & 0.75 & $0.482445 \mathrm{NS}$ & 61 \\
\hline \multirow{4}{*}{ after 30 s } & Error & - & - & 0 \\
& Species (1) & 0.07 & $0.799371 \mathrm{NS}$ & 66 \\
& Temperature (2) & 31.06 & $0.000000^{*}$ & 1 \\
& $(1) \times(2)$ & 0.63 & $0.537488 \mathrm{NS}$ & 33 \\
\hline \multirow{4}{*}{ after 60 s } & Error & - & - & 2 \\
& Species (1) & 1.20 & $0.282431 \mathrm{NS}$ & 45 \\
& Temperature (2) & 13.89 & $0.000054 *$ & 5 \\
& $(1) \times(2)$ & 1.57 & $0.224179 \mathrm{NS}$ & 48 \\
\hline
\end{tabular}

* Statistically significant influence of the factors, NS-non-statistically significant influence of the factors.

It is generally known that many processes take place on the surface of materials. The analysis of the surface properties of materials is particularly important during research on the finish or modification of their surface. Often, such an analysis makes it possible to predict the behavior of the material under certain conditions. The physicochemical parameters of the surface, strongly determined by the use or lack of additional modification methods, directly affect the way it interacts with factors such as water or organic solvents. In turn, this translates into resistance, or lack of resistance, to the factors that degrade the surface of the material. The analysis of the surface wettability of a given material over time makes it possible to determine the target resistance to the penetration of moisture into the material. It is known that the aging of coatings can cause defects (local damage to the coating, such as cracks) with a consequent increase in the water permeability of the coating. A direct indicator of this phenomenon is the change in the contact angle of the material surface over time, resulting from the penetration of moisture into the material.

\subsection{Wood Properties during Humidification at Different Relative Humidities}

The tauari wood exhibited higher equilibrium moisture content (EMC) than the iroko wood (Table 6). This was due to the lower content of chloroform-ethanol extractives in the tauari wood. Similar correlations were obtained for the hot water extractives (Table 3). This is confirmed by data from previous research, which demonstrate that the higher the content of extractive compounds, the lower the equilibrium moisture content of wood $[36,68]$ and the swelling rate [69].

The densified iroko and tauari wood were characterized by lower values of EMC than the non-densified wood (Table 6). As the temperature of the densification increased, the wood developed lower EMC. Heat treatment leads to changes in the structure of the chemical components of wood [70]. High treatment temperatures after densification reduce the hygroscopicity of wood [29,32]. A correlation between the extractives content and EMC was found [32]. The loss of volatile extractives may occur during thermal modification. A significant loss of polysaccharides in wood starts at around $180{ }^{\circ} \mathrm{C}$ [71]. In this study, 
changes in the content of soluble substances in $1 \% \mathrm{NaOH}$ were found after densification at modification temperatures of 100 and $150{ }^{\circ} \mathrm{C}$, but they were minor, at the level of 1 percentage point for the tauari and 1.5 percentage points for the iroko (Table 3 ). Under thermal modification, the condensation of lignin can occur, which can cause chemical changes in complexes with cellulose, reducing, to some extent, the interaction of hydroxyl groups with water [72,73]. Consequently, wood becomes more hydrophobic (displaying a low affinity with water) with increasing treatment temperatures [38].

Table 6. Equilibrium moisture content (EMC) of thermo-mechanically modified wood at different relative humidity $(\mathrm{RH}) ; \pm(\mathrm{SD})$.

\begin{tabular}{|c|c|c|c|c|c|c|}
\hline \multirow{3}{*}{$\begin{array}{c}\text { Wood } \\
\text { Species }\end{array}$} & \multirow{3}{*}{$\begin{array}{c}\text { Modification } \\
\text { Temperature } \\
\left.\text { ( }{ }^{\circ} \mathrm{C}\right)\end{array}$} & \multicolumn{5}{|c|}{ RH (\%) } \\
\hline & & 9 & 34 & 55 & 75 & 98 \\
\hline & & \multicolumn{5}{|c|}{ EMC (\%) } \\
\hline \multirow{3}{*}{ iroko } & non-modified & $2.8 \pm 0.1$ & $4.9 \pm 0.1$ & $7.6 \pm 0.1$ & $9.9 \pm 0.2$ & $18.8 \pm 0.6$ \\
\hline & 100 & $2.8 \pm 0.2$ & $4.7 \pm 0.2$ & $7.5 \pm 0.3 *$ & $9.0 \pm 0.5^{*}$ & $18.6 \pm 1.0$ \\
\hline & 150 & $1.9 \pm 0.1 *$ & $3.8 \pm 0.1 *$ & $5.6 \pm 0.1 *$ & $7.4 \pm 0.3^{*}$ & $17.8 \pm 0.6$ \\
\hline \multirow{3}{*}{ tauari } & non-modified & $3.4 \pm 0.1$ & $6.0 \pm 0.1$ & $9.6 \pm 0.1$ & $12.9 \pm 0.1$ & $22.3 \pm 0.2$ \\
\hline & 100 & $3.2 \pm 0.1^{*}$ & $5.9 \pm 0.1 *$ & $9.1 \pm 0.1$ * & $11.7 \pm 0.1$ * & $22.0 \pm 0.1$ \\
\hline & 150 & $2.8 \pm 0.1$ * & $5.1 \pm 0.1 *$ & $7.8 \pm 0.1$ * & $10.7 \pm 0.2$ * & $20.8 \pm 0.4$ * \\
\hline
\end{tabular}

* Statistically significant differences within the same species, based on the $t$-test ( $p \leq 0.05$; control group, nonmodified wood).

The iroko and tauari wood were densified in the radial direction. Therefore, the thermo-mechanically modified wood was characterised by higher swelling in the radial direction $\left(\mathrm{S}_{\mathrm{r}}\right)$ than in the tangential direction $\left(\mathrm{S}_{\mathrm{t}}\right)$ (Figure 5). These correlations were opposite to those for the non-modified wood. From previous research, it is known that in wood, swelling in the radial direction is lower than in the tangential direction, which is due to the anatomical structure of wood $[1,2,74,75]$. Along the radial section, layers of earlywood and latewood are placed alternately between each other. Earlywood is characterized by a lower density than latewood. This alternating placement attenuates the swelling. The highest swelling values are observed in the tangential direction, which is caused by the "spherical" orientation of the latewood layers, which undergo important dimensional changes. This happens due to a tangential elongation of the cellular lumens. Additionally, the middle lamella exerts a significant influence on the value of the swelling; its total thickness is greater in the tangential direction than in the radial direction $[74,75]$.

The thermo-mechanically modified wood, regardless of its modification temperature, was characterized by higher dimensional changes in the radial direction than the nondensified wood (Figure 5a,b). The iroko and tauari wood densified at $150{ }^{\circ} \mathrm{C}$ exhibited lower values of tangential swelling than the non-densified wood or the wood densified at $100{ }^{\circ} \mathrm{C}$ (Figure $\left.5 \mathrm{c}, \mathrm{d}\right)$. For the non-densified wood, $\mathrm{S}_{\mathrm{r}}$ was in a range between $0.7 \%( \pm 0.1 \%)$ and $3.8 \%( \pm 0.4 \%)$, depending on the RH (Figure $5 \mathrm{a}$ ). The iroko wood modified at $150{ }^{\circ} \mathrm{C}$ was characterized by lower $\mathrm{S}_{\mathrm{r}}$ values than the wood densified at $100{ }^{\circ} \mathrm{C}$. The $\mathrm{S}_{\mathrm{r}}$ of the iroko wood densified at $150{ }^{\circ} \mathrm{C}$ ranged from $1.5 \%( \pm 0.2 \%)$ to $7.2 \%( \pm 0.9 \%)$; for the iroko wood densified at $100{ }^{\circ} \mathrm{C}$, it was between $1.8 \%( \pm 0.3 \%)-12.4 \%( \pm 0.4 \%)$, depending on the $\mathrm{RH}$ (Figure $5 \mathrm{a})$. The $\mathrm{S}_{\mathrm{t}}$ of the iroko wood densified at $150{ }^{\circ} \mathrm{C}$ was $0.5 \%( \pm 0.1 \%)-2.7 \%( \pm 0.1 \%)$, which was lower than the $S_{t}$ of the wood densified at $100{ }^{\circ} \mathrm{C}(0.5 \%( \pm 0.1 \%)-4.1 \%( \pm 0.4 \%))$ and the $S_{t}$ of the non-modified iroko wood $(0.6 \%( \pm 0.1 \%)-5.9 \%( \pm 0.2 \%))$, depending on the RH (Figure 5c). 


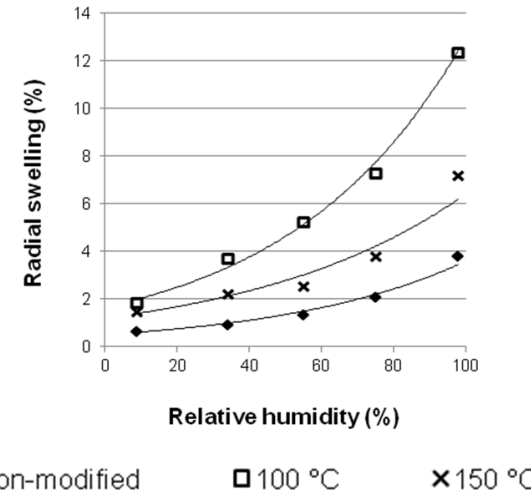

(a)

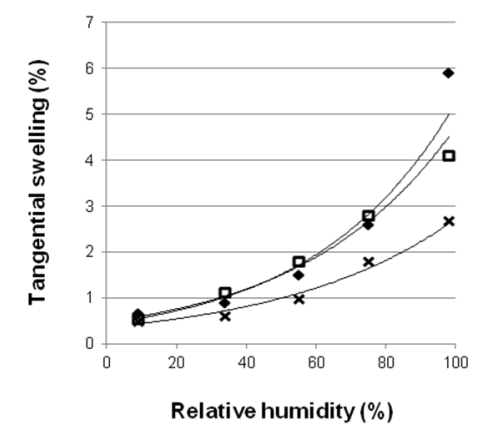

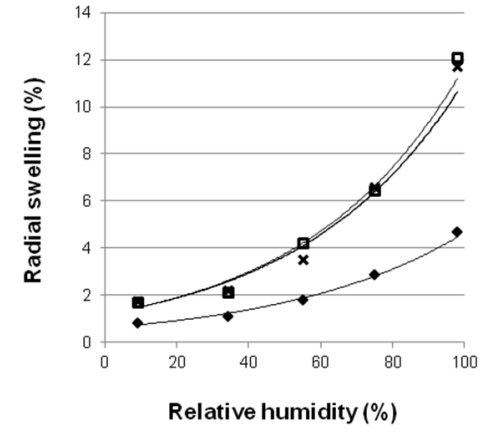

$\bullet$ non-modified

$\square 100^{\circ} \mathrm{C}$ $\times 150^{\circ} \mathrm{C}$

(b)

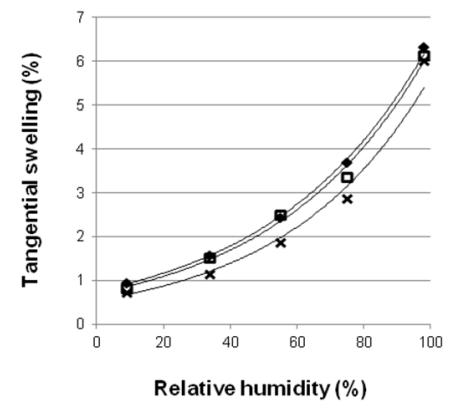

$\bullet$ non-modified

$\square 100^{\circ} \mathrm{C}$

$\times 150^{\circ} \mathrm{C}$

(d)

Figure 5. Dimensional changes of thermo-mechanically modified wood depending on relative humidity of air: (a) iroko—radial swelling; (b) tauari-radial swelling; (c) iroko-tangential swelling; (d) tauari-tangential swelling.

The $S_{r}$ of the tauari wood densified at $150{ }^{\circ} \mathrm{C}$ was similar to the $S_{\mathrm{r}}$ of the wood densified at $100{ }^{\circ} \mathrm{C}$. it ranged from $1.8 \%( \pm 0.1 \%)$ to $11.7 \%( \pm 0.4 \%)$ and from $1.7 \%( \pm 0.2 \%)$ to $12.1 \%( \pm 0.9 \%)$, respectively. For the non-densified tauari wood, values of $S_{\mathrm{r}}$ ranging from $0.8 \%( \pm 0.1 \%)$ to $4.7 \%( \pm 0.1 \%)$ were observed, depending on the RH (Figure $5 \mathrm{~b})$. The $\mathrm{S}_{\mathrm{t}}$ of the tauari wood (Figure $5 \mathrm{~d}$ ) densified at $100{ }^{\circ} \mathrm{C}$ was similar to that of the non-densified wood, ranging between $0.8 \%( \pm 0.1 \%)-6.1 \%( \pm 0.3 \%)$ and $0.9 \%( \pm 0.1 \%)-6.3 \%( \pm 0.1 \%)$, respectively. The $S_{t}$ of the tauari wood densified at $150{ }^{\circ} \mathrm{C}$, depending on the $\mathrm{RH}$, was in the range of $0.7 \%( \pm 0.1 \%)-6.0 \%( \pm 0.1 \%)$.

Fang et al. [76] stated that the increase in thickness of densified wood is caused by reversible and irreversible swelling. Reversible swelling is caused by the hygroscopic nature of wood, while irreversible swelling is caused by compression set recovery. It should also be noted that regardless of the densification temperature, the higher the $\mathrm{RH}$, the greater were the differences between the radial swelling of the densified wood and non-densified wood (Figure 5a,b). Under the influence of higher RH, greater changes in wood structure occurred, which were mainly the result of irreversible swelling. Some authors reported that increased internal stress in the material during the wood densification process resulting from an increase in the compression rate leads to higher values of springback $[49,57,77-79]$. Spring-back values increased due to an increase in the compression temperature $[49,79]$.

From a technological point of view, the anisotropy coefficient (the ratio between shrinkage or swelling in tangential and radial directions, respectively) is often analyzed [80]. For the non-densified iroko wood, the $S_{t} / S_{r}$ varied from 1.0 to 1.6 for $\mathrm{RH}$ of $9 \%-98 \%$ (Figure 6a), while for the densified iroko wood, the $S_{t} / S_{r}$ was from 0.3 to 0.4 , depending on the RH. For the densified tauari wood, the $S_{t} / S_{r}$ varied between 1.1 and 1.4 at $R H$ of $9 \%-$ $98 \%$ (Figure $6 b$ ). For the densified tauari wood, the $S_{t} / S_{r}$ ranged from 0.4 to 0.5 . There were 
no significant differences between the $S_{t} / S_{r}$ as a function of the densification temperature. This was observed for both the iroko (Figure 6a) and the tauari wood (Figure 6b).

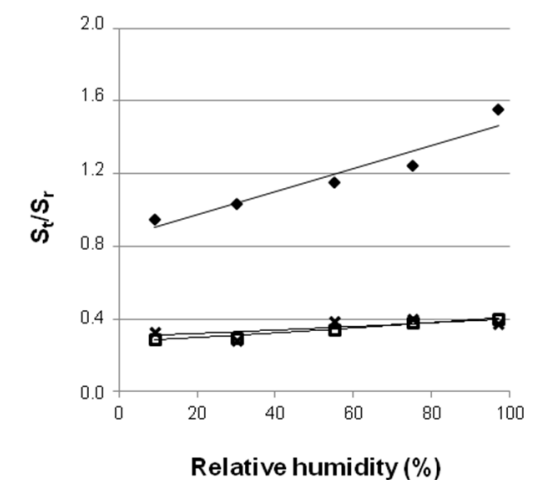

$\bullet$ non-modified

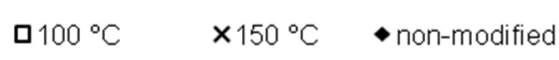

(a)

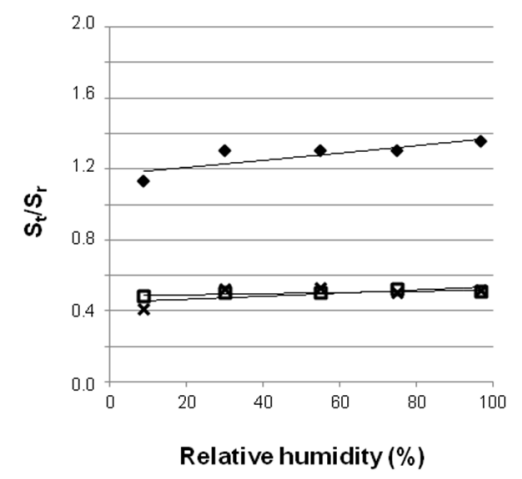

$\square 100^{\circ} \mathrm{C} \quad \times 150^{\circ} \mathrm{C}$

(b)

Figure 6. $S_{t} / S_{r}$ ratio of (a) iroko and (b) tauari wood before and after thermo-mechanical modification, depending on relative humidity of air.

A reduction in the swelling anisotropy was observed as a result of thermo-mechanical modification. This feature is especially important in the context of the use of wood for flooring materials exposed to the influence of changing room climates (as a result of changes in temperature and relative air humidity). It is important to note that the reduction in anisotropy is "relative" and represents the effect of an increase in swelling (dimensional changes) in the radial direction. However, both iroko and tauari wood densified at $150{ }^{\circ} \mathrm{C}$ displayed lower dimensional changes in the tangential direction than the non-modified wood.

As a result of dimensional changes of wood, its volume changes. A diffusion of water into the cell wall can cause only the transverse swelling of the cellulose fibers. Therefore, the dimensions of wood change mostly in the transverse direction, that is, tangentially and radially. The lowest changes in dimensions are observed in the longitudinal direction, due to the strong glycosidic bonds along the length of the cellulose chains, which cannot be broken by water molecules [74,75]. In analyzed cases, the volume swelling (VS) of the densified wood was determined by high values of swelling in the radial direction. The VS of the non-densified iroko wood ranged from $1.4 \%( \pm 0.1 \%)$ to $8.3 \%( \pm 0.7 \%)$, depending on the RH (Figure 7a). In general, it can be concluded that the VS of the iroko wood densified at $100{ }^{\circ} \mathrm{C}$ was about twice as high as the VS of the non-densified iroko wood, regardless of the RH level. For the iroko wood densified at $150{ }^{\circ} \mathrm{C}$, the multiplicity was about 1.3 . The exception was the VS of the iroko wood densified at $150{ }^{\circ} \mathrm{C}$ and conditioned at $9 \% \mathrm{RH}$, for which the multiplicity was 1.9 . The VS of the tauari wood densified at $100{ }^{\circ} \mathrm{C}$ was about 1.5 times greater than the VS of the non-densified tauari wood, regardless of the RH level (Figure $7 \mathrm{~b}$ ). For the tauari wood densified at $150{ }^{\circ} \mathrm{C}$, the multiplicity was similar (as for the iroko wood) and was about 1.4. Equations and curves describing the relations between the swelling (dimensional changes) of the iroko and tauari wood and the relative humidity are presented in Table 7. In the tests conducted, the relation between the swelling and the relative humidity was analyzed. The $R^{2}$ ratio was between 0.95 and 1.00 . The exception was the VS of the iroko wood densified at $150{ }^{\circ} \mathrm{C}$. In this case, $\mathrm{R}^{2}$ was 0.85 . Such high values of $R^{2}$ clearly indicate that using the given equations, it is possible to describe the dimensional changes of the densified iroko and tauari wood, depending on the relative air humidity. 


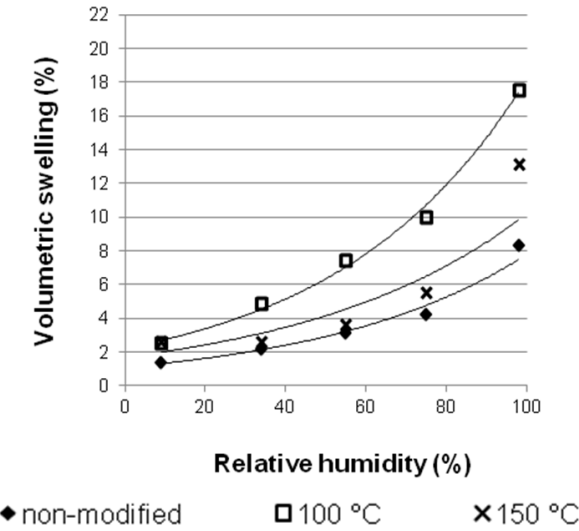

(a)

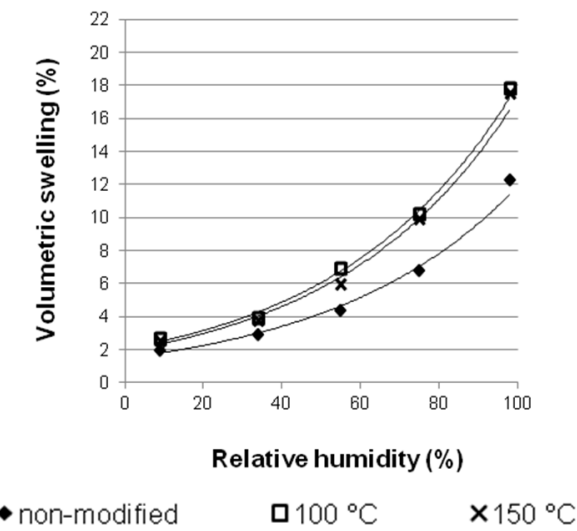

(b)

Figure 7. Volumetric swelling of (a) iroko and (b) tauari wood before and after thermo-mechanical modification, depending on relative humidity of air.

Table 7. Fitted curves predicting the swelling of non-densified and densified iroko and tauari wood at various relative humidity $(\mathrm{RH})$ values.

\begin{tabular}{|c|c|c|c|c|c|c|c|}
\hline \multirow{2}{*}{$\begin{array}{l}\text { Wood } \\
\text { Species }\end{array}$} & \multirow{2}{*}{$\begin{array}{c}\text { Modification } \\
\text { Temperature }\left({ }^{\circ} \mathrm{C}\right)\end{array}$} & \multicolumn{6}{|c|}{ Property } \\
\hline & & $\begin{array}{c}\text { Radial Swelling } \\
\left(\mathrm{S}_{\mathrm{r}}\right)\end{array}$ & $\mathbf{R}^{2}$ & $\begin{array}{c}\text { Tangential } \\
\text { Swelling }\left(S_{t}\right)\end{array}$ & $\mathbf{R}^{2}$ & $\begin{array}{c}\text { Volumetric } \\
\text { Swelling (VS) }\end{array}$ & $\mathbf{R}^{2}$ \\
\hline \multirow{3}{*}{ iroko } & non-modified & $\mathrm{S}_{\mathrm{r}}=0.5004 \mathrm{e}^{0.0197 R H}$ & 0.98 & $\mathrm{~S}_{\mathrm{t}}=0.4347 \mathrm{e}^{0.0249 R H}$ & 0.97 & $\mathrm{VS}=1.0861 \mathrm{e}^{0.0197 \mathrm{RH}}$ & 0.98 \\
\hline & 100 & $\mathrm{~S}_{\mathrm{r}}=1.6481 \mathrm{e}^{0.0206 \mathrm{RH}}$ & 0.99 & $S_{t}=0.4755 e^{0.0231 R H}$ & 0.99 & $\mathrm{VS}=2.2106 \mathrm{e}^{0.0211 R H}$ & 0.99 \\
\hline & 150 & $\mathrm{~S}_{\mathrm{r}}=1.1938 \mathrm{e}^{0.0168 \mathrm{RH}}$ & 0.95 & $\mathrm{~S}_{\mathrm{t}}=0.3598 \mathrm{e}^{0.0202 R H}$ & 0.97 & $\mathrm{VS}=1.6811 \mathrm{e}^{0.0181 \mathrm{RH}}$ & 0.85 \\
\hline \multirow{3}{*}{ tauari } & non-modified & $\mathrm{S}_{\mathrm{r}}=0.6222 \mathrm{e}^{0.0201 R H}$ & 0.99 & $S_{t}=0.7577 e^{0.0214 R H}$ & 1.00 & $\mathrm{VS}=1.4727 \mathrm{e}^{0.0209 \mathrm{RH}}$ & 0.99 \\
\hline & 100 & $\mathrm{~S}_{\mathrm{r}}=1.2081 \mathrm{e}^{0.0227 \mathrm{RH}}$ & 0.97 & $\mathrm{~S}_{\mathrm{t}}=0.7026 \mathrm{e}^{0.0219 R H}$ & 0.99 & $\mathrm{VS}=2.0315 \mathrm{e}^{0.0218 \mathrm{RH}}$ & 0.99 \\
\hline & 150 & $\mathrm{~S}_{\mathrm{r}}=1.2145 \mathrm{e}^{0.0221 R H}$ & 0.96 & $S_{t}=0.5441 e^{0.0234 R H}$ & 0.99 & $\mathrm{VS}=1.9064 \mathrm{e}^{0.0221 R H}$ & 0.99 \\
\hline
\end{tabular}

It should be noted that the dimensional changes of both modified and non-modified wood significantly affect its aesthetic values, and their analysis is used to predict the behavior of covering materials at the border with the wood surface, which determines the durability of the finishing coatings responsible for maintaining the protective and decorative function of the material.

\section{Conclusions}

This study demonstrates that the directions of the changes in the analyzed surface and the physical features of TMT wood were not the same. Generally, the thermo-mechanical treatment of wood influences the properties of wood in different ways; this influence depends on material factors (wood species, chemical composition, anatomical structure) and modification parameters. Based on our research, the following conclusions were defined:

- The iroko wood featured the highest density $\left(769 \pm 15 \mathrm{~kg} \cdot \mathrm{m}^{-3}\right)$ after modification at $100{ }^{\circ} \mathrm{C}$, while the tauari wood $\left(1098 \pm 27 \mathrm{~kg} \cdot \mathrm{m}^{-3}\right)$ featured the highest density after modification at $150{ }^{\circ} \mathrm{C}$.

- With the compression ratio at the level of approximately $35 \%$, the indicated density values were $36 \%$ and $58 \%$ higher, respectively, than the density of the non-modified iroko and tauari wood. Additionally, the iroko wood was less susceptible to TMT than the tauari wood due to an irregular fiber arrangement.

- The modification temperature influenced all the analyzed color parameters (with the exception of $b^{*}$ ) of the iroko and tauari wood, but was much smaller than in the case 
of the wood species-high color changes $(\Delta \mathrm{E}$ at $8.07 \pm 2.13)$ that occurred after the densification of the iroko wood at $150{ }^{\circ} \mathrm{C}$.

- $\quad$ After TMT, the iroko and tauari wood demonstrated different types of roughness changes, characterized by a weaker dynamics in the respective changes to the contact angle.

- The thermo-mechanically modified iroko and tauari wood exhibited lower EMC than the non-modified wood. The higher the densification temperature, the lower the EMC of the wood.

- The tauari wood featured higher EMC than the iroko wood. This was due to its lower content of chloroform-ethanol extractives and hot-water-soluble extractives.

- The densified wood displayed a greater tendency towards dimensional changes in climates with high relative air humidity, i.e., above $70 \%$, compared to the non-modified wood. The magnitude of the changes depended on the wood species and its processing parameters.

- The thermo-mechanically modified iroko and tauari wood were characterized by greater swelling in the radial direction than in the tangential direction, which was directly related to the wood densification direction.

Author Contributions: Conceptualization, A.L., M.M. and P.B.; methodology, A.L., P.B. and M.M.; formal analysis, A.L., P.B. and M.M.; investigation, A.L., M.M. and A.T.; resources, A.L., A.T. and P.B.; data curation, A.L. and M.M.; writing — original draft preparation, A.L. and M.M.; writing-review and editing, A.L., M.M. and P.B.; visualization, A.L. and A.T.; supervision, A.L., M.M. and P.B. All authors have read and agreed to the published version of the manuscript.

Funding: The research was funded by the Institute of Wood Sciences and Furniture, Warsaw University of Life Sciences-SGGW.

Institutional Review Board Statement: Not applicable.

Informed Consent Statement: Not applicable.

Data Availability Statement: The data presented in this study are available on request from the corresponding author.

Conflicts of Interest: The authors declare no conflict of interest.

\section{References}

1. Wagenführ, R. Holzatlas [The Atlas of Wood]; Fachbuchverlag Leipzig im Carl Hanser Verlag: München, Germany, 2007; pp. 521-523.

2. Glass, S.V.; Zelinka, S.L. Moisture Relations and Physical Properties of Wood; U.S. Department of Agriculture, Forest Service, Forest Products Laboratory: Madison, WI, USA, 2010; pp. 4-1-4-19.

3. Kretschmann, D.E. Mechanical Properties of Wood; U.S. Department of Agriculture, Forest Service, Forest Products Laboratory: Madison, WI, USA, 2010; pp. 5-1-5-46.

4. Kutnar, A.; Kamke, F.A. Influence of temperature and steam environment on set recovery of compressive deformation of wood. Wood Sci. Technol. 2012, 46, 953-964. [CrossRef]

5. Tu, D.; Su, X.; Zhang, T.; Fan, W.; Zhou, Q. Thermo-mechanical densification of Populus tomentosa var. tomentosa with low moisture content. Bioresources 2014, 9, 3846-3856. [CrossRef]

6. Zhan, J.F.; Avramidis, S. Needle fir wood modified by surface densification and thermal post-treatment: Hygroscopicity and swelling behaviour. Eur. J. Wood Wood Prod. 2016, 74, 49-56. [CrossRef]

7. Laskowska, A.; Sobczak, J.W. Surface chemical composition and roughness as factors affecting the wettability of thermomechanically modified oak (Quercus robur L.). Holzforschung 2018, 72, 993-1000. [CrossRef]

8. Blomberg, J.; Persson, B.; Blomberg, A. Effects of semi-isostatic densification of wood on the variation in strength properties with density. Wood Sci. Technol. 2005, 39, 339-350. [CrossRef]

9. Laskowska, A. Density profile and hardness of thermo-mechanically modified beech, oak and pine wood. Drewno 2020, 63, 25-41. [CrossRef]

10. Mania, P.; Wróblewski, M.; Wójciak, A.; Roszyk, E.; Moliński, W. Hardness of densified wood in relation to changed chemical composition. Forests 2020, 11, 506. [CrossRef]

11. Cruz, N.; Bustos, C.; Aguayo, M.G.; Cloutier, A.; Castillo, R. Impact of the chemical composition of Pinus radiata wood on its physical and mechanical properties following thermo-hygromechanical densification. Bioresources 2018, 13, 2268-2282. [CrossRef] 
12. Shi, J.; Peng, J.; Huang, Q.; Cai, L.; Shi, S. Fabrication of densified wood via synergy of chemical pretreatment, hot-pressing and post mechanical fixation. J. Wood Sci. 2020, 66, 5. [CrossRef]

13. Wood Flooring and Wood Panelling and Cladding-Determination of the Resistance to Chemical Agents; EN 13442; European Committee for Standardization: Brussels, Belgium, 2013.

14. Wood Flooring and Wood Panelling and Cladding-Determination of Dimensional Stability; EN 1910; European Committee for Standardization: Brussels, Belgium, 2016.

15. Wood Flooring and Parquet_-Determination of Resistance to Indentation-Test Method; EN 1534; European Committee for Standardization: Brussels, Belgium, 2020.

16. Candan, Z.; Hiziroglu, S.; Mcdonald, A.G. Surface quality of thermally compressed Douglas fir veneer. Mater. Des. 2010, 31, 3574-3577. [CrossRef]

17. Bekhta, P.; Salca, E.A.; Lunguleasa, A. Some properties of plywood panels manufactured from combinations of thermally densified and non-densified veneers of different thicknesses in one structure. J. Build. Eng. 2020, 29, 101116. [CrossRef]

18. CRIQ Forest products issued from 2nd transformation processes-Wood heat treatment [in French]. Report to the ministère des Ressources naturelles, de la Faune et des Parcs (MRNFP) by the centre de recherche industrielle du Québec (CRIQ) 2003.

19. Kutnar, A.; Hill, C. End of Life Scenarios and the Carbon Footprint of Wood Cladding, 1st ed.; CRC Press: Boca Raton, FL, USA, 2015; pp. 85-100.

20. Goli, G. Superficie del Legno Ottenuta Mediante Fresatura: Studio Delle Meccaniche di Formazione e dei Relativi Difetti. Surfaces de Bois Obtenues par de' Foncage: E' tude de la me' Canique de Formation et des de' Fauts Induits. Ph.D. Thesis, Universita' degli studi di Firenze, Ecole nationale superieur d'arts et metier, Cluny, France, 2003.

21. Thoma, H.; Peri, L.; Lato, E. Evaluation of wood surface roughness depending on species characteristics. Maderas-Cienc. Tecnol. 2015, 17, 285-292. [CrossRef]

22. Bekhta, P.; Krystofiak, T. The influence of short-term thermomechanical densification on the surface wettability of wood veneers. Maderas-Cienc. Tecnol. 2016, 18, 79-90. [CrossRef]

23. Gardner, D.J.; Generalla, N.C.; Gunnells, D.W.; Wolcott, M.P. Dynamic wettability of wood. Langmuir 1991, 7, $2498-2502$. [CrossRef]

24. Christiansen, A.W. Effect of overdrying of yellow-poplar veneer on physical properties and bonding. Holz Roh Werkst. 1994, 52, 139-149. [CrossRef]

25. Bach, S.; Belgacem, N.; Gandini, A. Hydrophobisation and densification of wood by different chemical treatments. Holzforschung 2005, 59, 389-396. [CrossRef]

26. Sivertsen, M.S.; Flæte, P.O. Water absorption in coated Norway spruce (Picea abies) cladding boards. Eur. J. Wood Wood Prod. 2012, 70, 307-317. [CrossRef]

27. Ayina, O.; Ngamveng, J.N.; Morlier, P. Densified wood and tropical wood. Comparative study of sorptive properties. Presented at the World Conference on Timber Engineering, Whistler, BC, Canada, July-August 2000.

28. Welzbacher, C.R.; Wehsener, J.; Rapp, A.O.; Halle, P. Thermo-mechanical densification combined with thermal modification of Norway spruce (Picea abies Karst) in industrial scale-Dimensional stability and durability aspects. Eur. J. Wood Wood Prod. 2008, 66, 39-49. [CrossRef]

29. Hill, C.A.S.; Ramsay, J.; Keating, B.; Laine, K.; Rautkari, L.; Hughes, M.; Constant, B. The water vapour sorption properties of thermally modified and densified wood. J. Mater. Sci. 2012, 47, 3191-3197. [CrossRef]

30. Laine, K.; Rautkari, L.; Hughes, M.; Kutnar, A. Reducing the set-recovery of surface densified solid Scots pine wood by hydrothermal post-treatment. Eur. J. Wood Wood Prod. 2013, 71, 17-23. [CrossRef]

31. Antikainen, T.; Paajanen, O.; Rautkari, L.; Kutnar, A.; Kamke, F.A.; Hughes, M. Simultaneous dryling and densification of silver birch (Betula pendula L.) veneers: Analysis of morphology, thickness swelling, and density profile. Wood Sci. Technol. 2014, 48, 325-336. [CrossRef]

32. Laskowska, A.; Marchwicka, M.; Boruszewski, P.; Wyszyńska, J. Chemical composition and selected physical properties of oak wood (Quercus robur L.) modified by cyclic thermo-mechanical treatment. Bioresources 2018, 13, 9005-9019. [CrossRef]

33. Kozakiewicz, P.; Matejak, M. Klimat a Drewno Zabytkowe. Dawna i Wspótczesna Wiedza o Drewnie [Climate and Antique Wood. Old-time and Contemporary Knowledge of Wood]; Warsaw University of Life Science Press: Warsaw, Poland, 2013; pp. 100-117.

34. Požgaj, A.; Chowanec, D.; Kurjatko, S.; Babiak, M. Štruktúra a Vlasnosti Dreva [Structure and Properties of Wood]; Príroda: Bratislava, Slovakia, 1993; pp. 54-66.

35. Gindl, M.; Reiterer, A.; Sinn, G.; Stanzl-Tschegg, S.E. Effects of surface ageing on wettability, surface chemistry, and adhesion of wood. Holz Roh Werkst. 2004, 62, 273-280. [CrossRef]

36. Popper, R.; Niemz, P.; Torres, M. Einfluss des Extraktstoffanteils ausgewählter fremdländischer Holzarten auf deren Gleichgewichtsfeuchte. Holz Roh Werkst. 2006, 64, 491-496. [CrossRef]

37. Antczak, A.; Radomski, A.; Zawadzki, J. Benzene substitution in wood analysis. Ann. Wars. Univ. Life Sci. SGGW For. Wood Technol. 2006, 58, 15-19.

38. Kocaefe, D.; Poncsak, S.; Doré, G.; Younsi, R. Effect of heat treatment on the wettability of white ash and soft maple by water. Holz Roh Werkst. 2008, 66, 355-361. [CrossRef] 
39. Diouf, P.N.; Stevanovic, T.; Cloutier, A.; Chang-Hua, F.; Blanchet, P.; Koubaa, A.; Mariotti, N. Effects of thermo-hygro-mechanical densification on the surface characteristics of trembling aspen and hybrid poplar wood veneers. Appl. Surf. Sci. 2011, 257, 3558-3564. [CrossRef]

40. Stamm, A.J.; Millett, M.A. The internal surface of cellulosic materials. J. Phys. Chem. 1941, 45, 43-54. [CrossRef]

41. Physical and Mechanical Properties of Wood-Test Methods for Small Clear Wood Specimens_Part 1: Determination of Moisture Content for Physical and Mechanical Tests; ISO 13061-1; International Organization for Standardization: Geneva, Switzerland, 2014.

42. Physical and Mechanical Properties of Wood-Test Methods for Small Clear Wood Specimens_Part 2: Determination of Density for Physical and Mechanical Tests; ISO 13061-2; International Organization for Standardization: Geneva, Switzerland, 2014.

43. TAPPI T 264 om-88. Preparation of Wood for Chemical Analysis; TAPPI Press: Atlanta, GA, USA, 1988.

44. TAPPI T $207 \mathrm{~cm}-99$. Water Solubility of Wood and Pulp; TAPPI Press: Atlanta, GA, USA, 1999.

45. TAPPI T 212 om-12. One Percent Sodium Hydroxide Solubility of Wood and Pulp; TAPPI Press: Atlanta, GA, USA, 2012.

46. Paints and Varnishes_Colorimetry—Part 3: Calculation of Colour Differences; ISO 7724-3; International Organization for Standardization: Geneva, Switzerland, 1984.

47. Geometrical Product Specifications (GPS)—Surface texture: Profile Method—Terms, Definitions and Surface Texture Parameters; ISO 4287; International Organization for Standardization: Geneva, Switzerland, 1997.

48. CIRAD 2012. Tauari. Tropix 7. Agricultural Research for Developmen. Available online: https://tropix.cirad.fr/ (accessed on 10 November 2021).

49. Pelit, H.; Emiroglu, F. Density, hardness and strength properties of densified fir and aspen woods pretreated with water repellents. Holzforschung 2021, 75, 358-367. [CrossRef]

50. İmirzi, H.Ö.; Ülker, O.; Burdurlu, E. Effect of densification temperature and some surfacing techniques on the surface roughness of densified Scots pine (Pinus sylvestris L.). Bioresources 2014, 9, 191-209. [CrossRef]

51. Kutnar, A.; Kamke, F.A.; Sernek, M. The mechanical properties of densified VTC wood relevant for structural composites. Holz Roh Werkst. 2008, 66, 439-446. [CrossRef]

52. Esteves, B.; Ribeiro, F.; Cruz-Lopes, L.; Domingos, H.F.I. Densification and heat treatment of maritime pine wood. Wood Res. 2017, 62, 373-388.

53. Laskowska, A. The influence of process parameters on the density profile and hardness of surface-densified birch wood (Betula pendula Roth). Bioesources 2017, 12, 6011-6023. [CrossRef]

54. DeGroot, W.; Pan, W.P.; Rahman, M.; Richards, G. First chemical events in pyrolysis of wood. J. Anal. Appl. Pyrol. 1988, 13, 221-231. [CrossRef]

55. Peters, J.; Fischer, K.; Fischer, S. Characterisation of emissions from thermally modified wood and their reduction by chemical treatment. Bioresources 2008, 3, 491-502. [CrossRef]

56. Gierlinger, N.; Jacques, D.; Grabner, M.; Wimmer, R.; Schwanninger, M.; Rozenberg, P.; Pâques, L.E. Colour of larch heartwood and relationships to extractives and brown-rot decay resistance. Trees 2004, 18, 102-108. [CrossRef]

57. Pelit, H. Colour characteristics of densified and thermally post-treated beech and pine woods. Mugla J. Sci. Technol. 2016, 2, 187-192. [CrossRef]

58. Cividini, R.; Travan, L.; Allegretti, O. White beech: A Tricky Problem in the Drying Process Procs. In Proceedings of the International Scientific Conference on Hardwood Processing (ISCHP), Québec City, QC, Canada, September 2007; pp. 135-140.

59. Klumpers, J.; Janin, G.; Becker, M.; Lévy, G. The influences of age, extractive content and soil water on wood color in oak: The possible genetic determination of wood color. Ann. Sci. For. 1993, 50 (Suppl. S1), 403s-409s. [CrossRef]

60. Gurleyen, L.; Esteves, B.; Ayata, U.; Gurleyen, T.; Cinar, H. The effects of heat treatment on colour and glossiness of some commercial woods in Turkey. Drewno 2018, 61, 201. [CrossRef]

61. McCurdy, M.C.; Pang, S.; Keey, R.B. Surface colour change in wood during drying above and below fibre saturation point. Maderas-Cienc. Tecnol. 2006, 8, 31-40. [CrossRef]

62. Li, W.; Wang, C.; Zhang, Y.; Jia, C.; Gao, C.; Jin, J. The influence of hot compression on the surface characteristics of poplar veneer. Bioresources 2014, 9, 2808-2823. [CrossRef]

63. Bernal, R.A.; Coradin, V.; Camargos, J.; Costa, C.; Pissarra, J. Wood anatomy of Lecythidaceae species called "tauari". IAWA J. 2011, 32, 97-112. [CrossRef]

64. Büyüksari, Ü. Surface characteristics and hardness of MDF panels laminated with thermally compressed veneer. Compos. B Eng. 2013, 44, 675-678. [CrossRef]

65. Papp, E.A.; Csiha, C. Contact angle as function of surface roughness of different wood species. Surf. Interfaces 2017, 8, 54-59. [CrossRef]

66. Bekhta, P.; Proszyk, S.; Krystofiak, T.; Lis, B. Surface wettability of short-term thermo-mechanically densified wood veneers. Eur. J. Wood Prod. 2015, 73, 415-417. [CrossRef]

67. Hakkou, M.; Petrissans, M.; Zoulalian, A.; Gerardin, P. Investigation of wood wettability changes during heat treatment on the basis of chemical analysis. Polym. Degrad. Stabil. 2005, 89, 1-5. [CrossRef]

68. Adamopoulos, S.; Voulgaridis, E. Effect of hot-water extractives on water sorption and dimensional changes of black locust wood. Wood Res. 2012, 57, 69-78.

69. Stamm, A.J.; Loughborough, W.K. Variation in shrinking and swelling of wood. Trans. Am. Soc. Mech. Eng. 1942, 64, 379-386. 
70. Mészáros, E.; Jakab, E.; Várhegyi, G. TG/MS, Py-GC/MS and THM-GC/MS study of the composition and thermal behavior of extractive components of Robinia pseudoacacia. J. Anal. Appl. Pyrolysis 2007, 79, 61-70. [CrossRef]

71. Hill, C. Wood Modification. Chemical, Thermal an Other Processes; Wiley: Hoboken, NH, USA, 2006; pp. 102-110.

72. Maunu, S. NMR studies of wood and wood products. Prog. Nucl. Magn. Reson. Spectrosc. 2002, 40, 151-174. [CrossRef]

73. Wideisen, E.; Wegener, G. Behaviour of lignin during thermal treatments of wood. Ind. Crop. Prod. 2008, 27, 157-162. [CrossRef]

74. Kollman, F.F.P.; Côté, W.A. Principles of Wood Science and Technology; Springer: Berlin/Heidelberg, Germany, 1968; pp. 204-219.

75. Skaar, C. Wood-Water Relations; Springer: Berlin/Heidelberg, Germany, 1988; pp. 127-138.

76. Fang, C.H.; Mariotti, N.; Cloutier, A.; Koubaa, A.; Blanchet, P. Densification of wood veneers by compression combined with heat and steam. Eur. J. Wood Prod. 2012, 70, 155-163. [CrossRef]

77. Wolcott, M.P.; Kasal, B.; Kamke, F.A.; Dillard, D.A. Testing small wood specimens in transverse compression. Wood Fiber. Sci. 1989, 21, 320-329.

78. Nairn, J.A. Numerical simulations of transverse compression and densification in wood. Wood Fiber. Sci. 2006, 38, 576-591.

79. Pelit, H.; Emiroglu, F. Effect of water repellents on hygroscopicity and dimensional stability of densified fir and aspen woods. Drona Ind. 2020, 71, 29-40. [CrossRef]

80. Christoforo, A.L.; de Almeida, T.H.; de Almeida, D.H.; dos Santos, J.C.; Panzera, T.H.; Lahr, F.A.R. Shrinkage for some wood species estimated by density. Int. J. Mater. Eng. 2016, 6, 23-27. [CrossRef] 